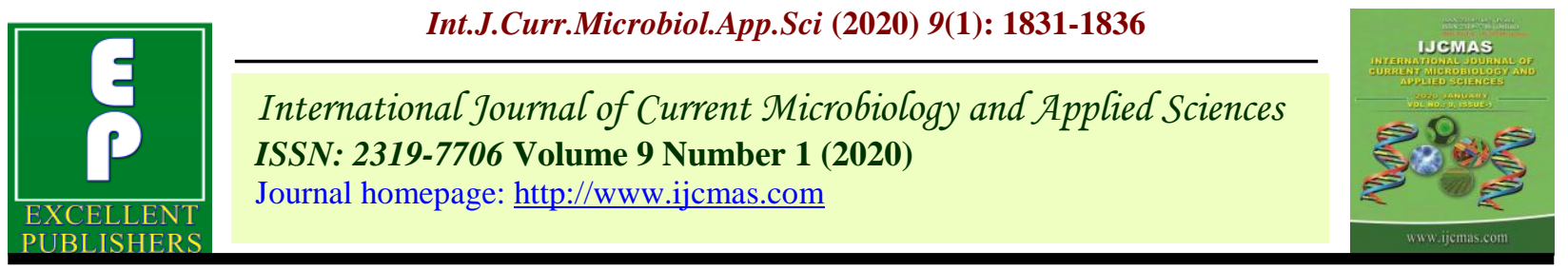

Original Research Article

https://doi.org/10.20546/ijcmas.2020.901.205

\title{
Impact Assessment of Frontline Demonstration on Mustard Productivity in Tribal District Pratapgarh of Rajasthan
}

\author{
Yogesh Kanojia* and R. K. Damor \\ ${ }^{1}$ Krishi Vigyan Kendra, Pratapgarh, Rajasthan, India \\ *Corresponding author
}

\section{Keywords}

Extension gap, FLD, Technology gap, Technology index, Mustard yield

Article Info

Accepted:

15 December 2019

Available Online:

20 January 2020

\section{A B S T R A C T}

Frontline demonstration (FLD) is one of the most powerful tools for transfer of technology. Keeping in view of an effective extension approach attempts are made by Krishi Vigyan Kendra, Pratapgarh to know the yield gaps and extent of technology adoption between improved package and practices under Front Line Demonstration (FLD) and farmer's practice (FP) of mustard crop. Front line demonstrations (FLDs) were conducted at 243 farmers' fields to demonstrate the impact of improved agro-techniques on production and economic benefits from 2014-15 to 2018-19. The technologies demonstrated in FLDs recorded additional return over farmers practice. Under FLDs the yield of mustard was increased by 19.97 per cent over farmers practice. The extension gap, technology gap and technology index were calculated as $2.66 \mathrm{q} / \mathrm{ha}, 6.03 \mathrm{q} / \mathrm{ha}$ and 27.18 per cent, respectively. Adoption of improved package of practices in mustard cultivation recorded higher B:C ratio (2.25) as compare to FP (1.79). Yield enhancement and higher net returns observed under FLDs through improved technologies of mustard. Thus, the productivity of mustard could be increased with the adoption of recommended improved package of practices. The present study resulted to convincing the farming community for higher productivity and returns.

\section{Introduction}

Available agricultural technology does not serve its purpose till it reaches and adopted by its ultimate users, the farmers. Technology transfer refers to the spread of new ideas from originating sources to ultimate users (Prasad et al., 1987). Frontline Demonstration (FLD) is the concept of field demonstration evolved by the Indian Council of Agricultural Research with the inception of the
Technology Mission on Oilseed Crops during mid-eighties. The field demonstrations conducted under the close supervision of scientists of the National Agriculture Research System is called front-line demonstrations because the technologies are demonstrated for the first time by the scientists themselves before being fed into the main extension system of the State Department of Agriculture. Frontline demonstration (FLD) is one of the most 
powerful tools of extension because farmers, in general, are driven by the perception that 'Seeing is believing'.

Mustard (Brassica juncea L.) is an important rabi season oilseed crop, belongs to family Cruciferae and genus Brassica. Mustard is the world's second leading source of vegetable oil, after soybean. It is mainly grown in northern part of India. Rajasthan is the largest producing state followed by Uttar Pradesh. Mustard seed contains average $34-43 \%$ oil content and contributes for $32 \%$ of total edible oil. The total production of this crop in India is 8.08 MT with a productivity of 1420 $\mathrm{kg} / \mathrm{ha}$. In Rajasthan, rapeseed and mustard occupies prime place amongst all the oilseed crops grown in the state, occupying $6.5 \mathrm{~m}$. hectares area, with production of $3.5 \mathrm{~m}$ tones and $1208 \mathrm{~kg} / \mathrm{ha}$ average yield Sodani et al., (2017). As such there always appears to be a gap between the recommended technology by the scientist and it's modified from at the farmer's level. The technology gap is thus the major problem in the efforts of increasing agricultural production in the country. Realizing the importance of frontline demonstrations in transfer of technologies, Krishi Vigyan Kendra, Pratapgarh has been conducting FLDs on mustard since 2014-15 in different villages of Pratapgarh district of Rajasthan with the objective of convincing farmers and extension functionaries together about the production potentialities of the mustard technologies for further wide scale diffusion. In view of the above factors, frontline demonstrations were undertaken in a systematic manner on farmer's field to show the worth of a new variety and convince the farmers to adopt improved cultivation practices of mustard for increasing productivity. Keeping in view the present investigation attempts to study the yield gaps between frontline demonstration trails and farmers yield, extend of technology adoption and benefit cost ratio.

\section{Materials and Methods}

Krishi Vigyan Kendra, Pratapgarh, Rajasthan conducted 243 Front Line Demonstration in 110 ha area under real farming situations from 2014-15 to 2018-19. For the purpose, ten villages namely Amlikheda, Bhatkhedi, Dabra, Piplia, Jawaharnagar, Motikhedi, Devgarh, Tila, Meriakhedi and Jodamahura of Pratapgarh district were selected. The detailed guidance regarding scientific cultivation practices of mustard were given to the farmers to increase awareness about improved technology and to increase productivity of mustard through conducting training programmes by KVK Scientists. All other steps like site and farmer selection, layout of demonstration, farmer's participation etc. were followed as suggested by Choudhary (1999). Yield data were collected from demonstration plots and control (Farmer's practice). The front line demonstrations were conducted to study the gaps between the potential yield and demonstration yield, extension gap and the technology index. Economic, additional cost \& returns, B:C ratio were also calculated. To estimate technology gap, extension gap and technology index the following formulae have been used (Samui et al., 2000).

1. Percent increase yield = (Demonstration yield - farmers yield)/ farmers yield X 100

$\begin{aligned} & \text { 2. Technology Gap } \\ & \text { yield- Demonstration Yield }\end{aligned}=\quad$ Potential

3. Extension Gap = Demonstration Yield- Farmer Yield
4. Technology Index = (Technology Gap/ Potential Yield) x 100

5. Benefit-Cost ratio $=\quad$ Net returns/Cost of cultivation 


\section{Results and Discussion}

\section{Yield parameters}

The data on mustard yield (Table-2) indicated that the FLDs had a good impact on the farming community of Pratapgarh district as they were motivated by the new production technologies adopted in the demonstrations. Average mustard yield under front line demonstrations was observed as $16.04 \mathrm{q} / \mathrm{ha}$ which was higher by $19.97 \%$ over the prevailing farmers practice $(13.37 \mathrm{q} / \mathrm{ha})$. The results are in close conformity with the research results of Sharma et al. (2016).

\section{Extension gap and Technology gap}

The extension and technology gap are 2.66 $\mathrm{q} / \mathrm{ha}$ and $6.03 \mathrm{q} / \mathrm{ha}$, respectively during the period of demonstration (Table-2). This emphasized the need to educate the farmers through various means for the adoption of improved agricultural production technologies to reverse this trend of wide extension gap. More and more use of latest production technologies with high yielding varieties will subsequently change this alarming trend of galloping extension gap. The new agrotechniques will eventually lead to the farmers to replace old varieties with the new one. The technology gap observed may be attributed to the dissimilarity in the soil fertility status and weather conditions. Hence, variety wise location specific recommendation appears to be necessary to minimize the technology gap for yield level in different situations.

\section{Technology index}

The technology index indicates the feasibility of the evolved technology at the farmer's fields. The lower the value of technology index more is the feasibility of the technology. The data (Table-2) showed that lowest technology index value $19.68 \%$ was noticed in the year 2015-16, while in the year 2016-17 the value was $35.38 \%$ which was found maximum during the study period, whereas the average value of technology index was recorded $27.18 \%$, it may be due to uneven and erratic weather conditions of the area. The results are corroborating with the findings of Hiremath and Nagaraju (2009) and Dhaka et al. (2010).

Table.1 Comparison between demonstration package and existing practices under mustard FLDs

\begin{tabular}{|c|c|c|c|}
\hline S. No. & Particulars & Demonstrations & Farmers practice \\
\hline 1 & Farming Situation & Irrigated & Irrigated \\
\hline 2 & Variety & Vasundhara, NRCDR-02 and RH-406 & Laxmi/Local \\
\hline 3 & Time of sowing & $\begin{array}{l}\text { Seed treated with Imidachloprid } 7.5 \mathrm{~g} / \mathrm{kg} \\
\text { seed }\end{array}$ & No seed treatment \\
\hline 4 & Method of sowing & $15^{\text {th }}$ September to $15^{\text {th }}$ October & $\begin{array}{l}1^{\text {th }} \text { September to } 20^{\text {th }} \\
\text { October }\end{array}$ \\
\hline 5 & Seed Treatment & Line sowing with 30 to $45 \mathrm{~cm}$ spacing & Broad casting \\
\hline 6 & Seed rate & $2.0-2.5 \mathrm{~kg} / \mathrm{ha}$ & $4.0-5.0 \mathrm{~kg} / \mathrm{ha}$ \\
\hline 7 & Fertilizer dose & 60:40 (NP kg/ha) and 250kg gypsum & 18:40 (NP kg/ha) \\
\hline 8 & Plant Protection & $\begin{array}{l}\text { Need based application of Imidachloprid } \\
\text { against painted bug and aphids }\end{array}$ & Nil \\
\hline
\end{tabular}


Table.2 Yield performance of mustard under frontline demonstrations and famers practice

\begin{tabular}{|c|c|c|c|c|c|c|c|c|c|}
\hline \multirow[t]{2}{*}{ Year } & \multirow[t]{2}{*}{ Demo. Variety } & \multirow{2}{*}{$\begin{array}{l}\text { No. of } \\
\text { Demo. }\end{array}$} & \multirow{2}{*}{$\begin{array}{l}\text { Area } \\
\text { (ha) }\end{array}$} & \multicolumn{2}{|c|}{ Yield (q/ha) } & \multirow{2}{*}{$\begin{array}{l}\text { \% increase } \\
\text { over check }\end{array}$} & \multirow{2}{*}{$\begin{array}{l}\text { Extension } \\
\text { gap (q/ha) }\end{array}$} & \multirow{2}{*}{$\begin{array}{l}\text { Technology } \\
\text { gap (q/ha) }\end{array}$} & \multirow{2}{*}{$\begin{array}{c}\text { Technology } \\
\text { index }(\%)\end{array}$} \\
\hline & & & & Demo. & Check & & & & \\
\hline 2014-15 & Vasundhara & 15 & 10 & 16.15 & 15.17 & 6.46 & 0.98 & 4.94 & 23.42 \\
\hline 2015-16 & Vasundhara & 15 & 10 & 16.94 & 14.85 & 14.07 & 2.09 & 4.15 & 19.68 \\
\hline 2016-17 & NRCDR-02 & 43 & 20 & 14.30 & 10.70 & 33.64 & 3.6 & 7.83 & 35.38 \\
\hline 2017-18 & RH-406 & 95 & 40 & 16.29 & 12.85 & 26.77 & 3.44 & 6.71 & 29.17 \\
\hline 2018-19 & RH-406 & 75 & 30 & 16.5 & 13.3 & 24.06 & 3.2 & 6.5 & 28.26 \\
\hline Average & & 243 & 110 & 16.04 & 13.37 & 19.97 & 2.66 & 6.03 & 27.18 \\
\hline
\end{tabular}

Table.3 Economics, additional cost and returns in mustard under frontline demonstrations and famers practice

\begin{tabular}{|c|c|c|c|c|c|c|c|c|c|c|}
\hline \multirow[t]{2}{*}{ Year } & \multicolumn{2}{|c|}{ Cost of Cultivation } & \multicolumn{2}{|c|}{ Gross Return } & \multicolumn{2}{|c|}{ Net Return } & \multicolumn{2}{|c|}{ B:C Ratio } & \multirow{2}{*}{$\begin{array}{c}\text { Additional } \\
\text { Cost in } \\
\text { Demonstration } \\
\text { (Rs./ha) }\end{array}$} & \multirow{2}{*}{$\begin{array}{c}\text { Additional } \\
\text { Return in } \\
\text { Demonstration } \\
\text { (Rs./ha) }\end{array}$} \\
\hline & Demo. & FP & Demo. & FP & Demo. & FP & Demo. & FP & & \\
\hline 2014-15 & 14800 & 14500 & 47643 & 44752 & 32843 & 30252 & 2.22 & 2.09 & 300 & 2591 \\
\hline 2015-16 & 15240 & 14950 & 49973 & 44752 & 34733 & 29802 & 2.28 & 1.99 & 290 & 4931 \\
\hline 2016-17 & 15900 & 15200 & 48620 & 36380 & 32720 & 21180 & 2.06 & 1.39 & 700 & 11540 \\
\hline 2017-18 & 16850 & 16350 & 57016 & 44986 & 40166 & 28636 & 2.38 & 1.75 & 500 & 11530 \\
\hline 2018-19 & 17400 & 16800 & 57750 & 46550 & 40350 & 29750 & 2.32 & 1.77 & 600 & 10600 \\
\hline Average & 16038 & 15560 & 52200 & 43484 & 36162 & 27924 & 2.25 & 1.79 & 478 & 8238 \\
\hline
\end{tabular}




\section{Economic analysis}

The average cost of cultivation Rs. 16038/ha involved in FLDs as compared to Rs. 15560/ha under farmers practice (Table-3). The FLDs plots fetched higher average gross returns (Rs. 52200/ha) and net returns (Rs. 36162/ha) with higher benefit: cost ratio (2.25) as compared to gross returns (Rs. 43484/ha), net returns Rs. (27924/ha) and benefit: cost ratio (1.79) with farmers practice. Hiremath and Nagaraju (2009), Sreelakshmi et al. (2012) and Joshi et al. (2014) also reported higher net returns and $\mathrm{B}: \mathrm{C}$ ratio in the FLDs on improved technologies compared to the farmers practices and are at par with results of the present study which also resulted in higher net returns through FLDs on improved technologies.

\section{Additional cost of cultivation and returns}

Further, data (Table-3) revealed that the average additional cost of cultivation (Rs. 478/ha) under mustard demonstrations yielded additional net returns of Rs. 8238/ha. The results suggest that mustard demonstrations have higher profitability and economic viability of under local agroecological situation.

Thus, it may be concluded that the yield and returns in mustard crop increased substantially with the improved production technologies. However, the yield level under FLDs was better than the farmer practice and performance of these varieties could be further improved by adopting recommended production technologies. So, there is need to disseminate the improved technologies among the farmers with effective extension methods like training and field demonstrations. The farmers should be encouraged to adopt the recommended agro-techniques for getting maximum returns in specific locations.

\section{References}

Choudhary B.N. (1999). Krishi Vigyan Kendra - A guide for KVK managers. Publication, Division of Agricultural Extension, ICAR. pp 73-78.

Dhaka, B.L., Meena, B.S. and Suwalka, R.L. 2010. Popularization of improved maize production technology through frontline demonstrations in south-eastern Rajasthan. J. Agril. Sci. 1(1):39-42.

Hiremath, S.M. and Nagaraju, M.V. 2009. Evaluation of front line demonstration trials on onion in Haveri district of Karnataka. Karnataka J. Agril. Sci. 22(5):1092-1093.

Joshi, N.S., Bariya, M.K. and Kunjadia, B.B. 2014. Yield gap analysis through front line demonstrations in wheat crop. International J. Scientific Res. Pub. 4(9): 1-3.

Prasad C., Chaudhary B. N. and Nayar B. B. (1987). First Line Transfer of Technology Project, ICAR, New Delhi. pp 87

Sharma, V., Kumar, V., Sharma, S.C. and Singh, S. 2016. Productivity enhancement and popularization of improved production technologies in wheat through frontline demonstrations. Journal of Applied and Natural Science 8(1): 423- 428.

Sodani R., Seema, Singhal R.K., Gupta S., Gupta N., Chauhan K.S. and Chauhan J. (2017) "Performance of yield and yield attributes of ten Indian Mustard (Brassica juncea L.) Genotypes under drought stress". Int. J. Pure App. Biosci. 5 (3): 467-476.

Sreelakshmi, C.H., Sameer, K., C.V. and Shivani, D. 2012. Productivity enhancement of pigeonpea through improved production technology. Madras Agril. J. 99(4-6):248-250.

Samui, S.K., Mitra, S., Roy, D.K., Mandal, A.K. and Saha, D. (2000). Evaluation of 
front line demonstration on groundnut. 18(2):180-183.

J. Indian Soc. Coastal Agric. Res.,

\section{How to cite this article:}

Yogesh Kanojia and Damor, R. K. 2020. Impact Assessment of Frontline Demonstration on Mustard Productivity in Tribal District Pratapgarh of Rajasthan. Int.J.Curr.Microbiol.App.Sci. 9(01): 1831-1836. doi: https://doi.org/10.20546/ijcmas.2020.901.205 